\title{
Retraction Note: circRNA_100290 plays a role in oral cancer by functioning as a sponge of the miR-29 family
}

\author{
L. Chen ${ }^{1} \cdot$ S. Zhang ${ }^{1} \cdot$ J. Wu ${ }^{2} \cdot$ J. Cui ${ }^{3} \cdot$ L. Zhong ${ }^{1} \cdot$ L. Zeng $^{1} \cdot$ S. Ge ${ }^{1}$
}

Published online: 13 June 2019

(c) The Author(s) 2019. This article is published with open access

Retraction Note to: Oncogene (2017) 36:4551-4561

https://doi.org/10.1038/onc.2017.89

published online 3 April 2017

The authors have retracted this article because it contains serious errors in Figs. $5 \mathrm{c}$ and $7 \mathrm{~b}$, resulting from the data collection process. As such, the authors are no longer confident in the conclusions drawn within this article. All authors agree to this retraction.
Open Access This article is licensed under a Creative Commons Attribution-NonCommercial-NoDerivatives 4.0 International License, which permits any non-commercial use, sharing, distribution and reproduction in any medium or format, as long as you give appropriate credit to the original author(s) and the source, and provide a link to the Creative Commons license. You do not have permission under this license to share adapted material derived from this article or parts of it. The images or other third party material in this article are included in the article's Creative Commons license, unless indicated otherwise in a credit line to the material. If material is not included in the article's Creative Commons license and your intended use is not permitted by statutory regulation or exceeds the permitted use, you will need to obtain permission directly from the copyright holder. To view a copy of this license, visit http://creativecommons.org/licenses/by-nc-nd/4.0/. $\triangle$ L. Chen

drlc2011@163.com

1 Department of Oral and Maxillofacial Surgery, The Second Xiangya Hospital, Central South University, Changsha, P.R. China

2 Department of Stomatology, People's Hospital of New District Longhua Shenzhen, Shenzhen, P.R. China

3 State Key Laboratory of Oral Diseases, Sichuan University, Chengdu, P.R. China 